\title{
Isolation and screening lactic acid bacteria for riboflavin production and their use for bioenrichment of curd
}

\author{
Chaya, S. Patil, K. S. Jagadeesh* and A. S. Noor Nawaz \\ Department of Agricultural Microbiology, University of Agricultural Sciences, Dharwad- 580005 (Karnataka), \\ INDIA \\ *Corresponding author. E-mail:jagsbio@gmail.com \\ Received: July 16, 2015; Revised received: January 1, 2016; Accepted: April 4, 2016
}

\begin{abstract}
As many as 47 lactic acid bacteria were isolated from various vegetables and fruits and raita collected from local households and characterized. All of them were Gram positive and catalase negative. The isolates were screened for riboflavin production. The riboflavin production varied from 0.86 to $10.90 \mathrm{mg} \mathrm{L}^{-1}$. The isolate Ra1 produced the highest riboflavin (10.90 ppm). Incidentally, it also produced 5.6 per cent lactic acid and $21.4 \mathrm{ppm}$ exopolysaccharide (EPS). Similarly, N2 and F2 isolates produced 10.90 and $10.20 \mathrm{ppm}$ riboflavin and 21.17 and $21.24 \mathrm{ppm}$ EPS, respectively. These three selected isolates were used for preparing a functional curd and evaluated. The curd produced by inoculating N2 and Ra1 were of very good quality with excellent flavor, taste and texture and smooth cutting quality. Ra1 produced a functional curd with the highest riboflavin content (13.97 ppm). $\mathrm{N} 2$ and RA1 resulted in very high acceptability index of 95.37 and 94.44 per cent, respectively. The better organoleptic parameters of the functional curd may also be due to high lactic acid and exopolysaccharide production by these isolates. Thus, by inoculating riboflavin synthesizing $L A B$ isolates to curd, riboflavin-enriched functional curd with enhanced consumer appeal, can be produced.
\end{abstract}

Keywords: Exopolysaccharide, Functional curd, Lactic acid bacteria, Riboflavin

\section{INTRODUCTION}

Lactic acid bacteria (LAB) are an important group of industrial microorganisms used in various food and dairy industries due to their fermentative properties. LABS are considered as generally regarded as safe (GRAS) organisms and their application as probiotics is immense as they play major role in maintaining health (Stiles, 2004). They produce a range of nutraceuticals, which include $\mathrm{B}$ vitamins like riboflavin (B2), folate (B11) and cobalamine (B12), low calorie sugars like mannitol and sorbitol, exopolysaccharides, diacetyl and L-alanine. A large number of lactic acid bacteria such as Lactobacillus acidophilus, $L$. bulgaricus, L. plantarum, L. reuteuri, L. delbrueckii, $L$. rhamnosus, L. lactis and Lactococcus cremoris, Bifidobacteria infantis, and B. longum have been reported to produce riboflavin (Capozzi et al., 2011).

Riboflavin is a basic component of cellular metabolism and is a part of Vitamin B group. It is an indispensable component in the human diet, which is the precursor of flavin mononucleotide (FMN) and flavin adenine dinucleotide (FAD) (Vitreschak et al., 2002). It is required for metabolism of fats, carbohydrates and proteins. It is also used in small amounts as a coloring agent in foods such as ice cream and sauces. The recommended daily allowance of riboflavin is $1.6 \mathrm{mg}$ and the deficiency of riboflavin leads to loss of hair, inflammation of the skin, sore throat, hyperemia, edema of oral and mucous membranes, cheilosis and glossitis (Sybesma et al., 2004). Although riboflavin is found in a wide variety of foods, its deficiency is common in many parts of the world, particularly in developing countries (Boisvert et al., 1993). As mammalian cells cannot synthesize riboflavin, the riboflavin synthesizing LAB can be used to augment its content in bio-enrichment of curd. The deficiency can be treated with dietary supplement of riboflavin or by consuming fermented foods such as cheese, yogurt fortified with riboflavin in the daily diet. Riboflavin has traditionally been produced by chemical processes, but in recent times, this has been replaced by the microbial fermentation processes (Stahmann et al., 2004). This study was aimed to isolate riboflavin producing LAB strains from different sources and their utilization for producing a curd rich in riboflavin.

Hence, in this study an attempt was made to isolate LAB from diverse sources and screen them for higher riboflavin production. The efficient high riboflavin producing $\mathrm{LAB}$ isolates were then used to inoculate to milk to study their effect on sensory attributes as well as riboflavin content of the curd produced.

\section{MATERIALS AND METHODS}

Sample collection and isolation: Various vegetables such as bitter gourd, cucumber, cabbage, capsicum and 
fruits like pomegranate, tomato, onion and green chilli, were collected from Dharwad market and used in the study. Traditional fermented foods including raita and sauerkraut were collected from local households. Different flowers such as Antigonan, Petunia, Zinnia and Calenduala were collected from UAS Campus Garden, Dharwad and were used for LAB isolation. From all these samples, lactic acid bacteria were isolated using the MRS medium (de Man et al., 1960). After $48 \mathrm{~h}$, the representative colonies were picked up and purified. The purified colonies were maintained on MRS slants and stored at $4^{\circ} \mathrm{C}$ for use as working culture. The morphology of cells, Gram reaction and catalase assays were done. Riboflavin producing ability of the isolates was assessed as described by Sauer et al. (1996). The culture broth $(0.8 \mathrm{ml})$ was mixed with 0.2 $\mathrm{ml}$ of $1 \mathrm{M} \mathrm{NaOH}$. A $0.4-\mathrm{ml}$ volume of the resulting solution was neutralized with $1 \mathrm{ml}$ of $0.1 \mathrm{M}$ potassium phosphate buffer ( $\mathrm{pH}$ 6.0), and the absorbance read in a spectrophotometer at $444 \mathrm{~nm}$. The riboflavin concentration was calculated using an extinction coefficient of $1.04 \times 10^{-2} \mathrm{M}^{-1} \mathrm{~cm}^{-1}$. The isolates were also screened for citric acid (AOAC, 1995) and exopolysaccharide (Kojic et al., 1992) production.

Preparation of a functional curd using riboflavin producing selected LAB isolates: The milk (UAS Dairy) was boiled and cooled to room temperature. To $100 \mathrm{ml}$ milk, $1 \mathrm{ml}$ curd culture (commercial curd) was added. The preparation was made in 4 treatments.

1. Milk $(100 \mathrm{ml})+$ Curd culture $(1 \mathrm{ml})$

2. Milk $(100 \mathrm{ml})+$ Curd culture $(1 \mathrm{ml})+$ isolate $\mathrm{N} 2$ $\left(250 \mu 1\right.$, having a population of $\left.194 \times 10^{7} \mathrm{cfu} / \mathrm{ml}\right)$

3. Milk $(100 \mathrm{ml})+$ Curd culture $(1 \mathrm{ml})+$ F2 $(250 \mu 1$, $\left.208 \times 10^{7} \mathrm{cfu} / \mathrm{ml}\right)$

4. Milk (100ml) + Curd culture (1ml) + Ra1 $(250 \mu 1$, $168 \times 107 \mathrm{cfu} / \mathrm{ml})$

After mixing, they were incubated at $37^{\circ} \mathrm{C}$ for $6 \mathrm{~h}$. After 6 hours, the organoleptic tests were carried out, involving a panel of judges, to assess the consistency, color, flavor, taste, texture and cutting capacity, following the Hedonic scale (Meilgaard et al., 2007). Riboflavin content in the curd was also estimated following the spectrophotometer method (Sauer et al.,1996).

\section{RESULTS AND DISCUSSION}

As many as 47 predominant bacteria were isolated on MRS medium and purified. All of them were Gram positive and catalase negative. Morphologically, most of them were rods, and some were cocci shaped. They were screened for riboflavin production. The riboflavin production varied from 0.86 to $10.90 \mathrm{mgL}^{-1}$. Some of the isolates viz., Ra1, F2 and N2 produced more than $10.00 \mathrm{mg} \mathrm{L}^{-1}$. Ral produced $10.90 \mathrm{ppm}$ riboflavin. Incidentally, it also produced 5.6 per cent lactic acid and $21.4 \mathrm{ppm}$ exopolysaccharide (EPS). Similarly, N2 and F2 isolates produced 10.90 and 10.20 ppm riboflavin and 21.17 and 21.24 ppm EPS, respectively.
Hence, these three isolates were selected for preparing a functional curd and the curd evaluated.

It can be seen from the table 1 that the isolates $\mathrm{N} 2$ and Ral produced very good quality curd with excellent flavor, very good taste and texture and smooth cutting quality. And, Ra1 resulted in a functional curd with the highest riboflavin content (13.97 ppm). Similarly, Del Valle et al. (2014) screened LAB for high riboflavin content and observed that certain strains showed an extracellular concentration of riboflavin above $190 \mathrm{ng} /$ $\mathrm{mL}$ reaching high values of $260 \mathrm{ng} / \mathrm{mL}$. The levels of riboflavin produced by these strains were higher than those described by Capozzi et al. (2011) in LAB isolated from sourdough. The strain Lactobacillus plantarum CRL 725 was able to significantly increase the initial concentration of riboflavin in soy milk from 309 $\pm 9 \mathrm{ng} / \mathrm{mL}$ to $700 \pm 20 \mathrm{ng} / \mathrm{mL}$ after $12 \mathrm{hrs}$ of incubation at $37{ }^{\circ} \mathrm{C}$. Roseoflavin resistant variants of this strain were obtained and evaluated in soymilk. One of the variant strains increased 6 times $(1860 \pm 20 \mathrm{ng} /$ $\mathrm{mL}$ ) the initial riboflavin levels of soy milk. Using this strain, they produced a fermented soymilk with elevated concentrations of riboflavin. A $200 \mathrm{~mL}$ portion of the soy milk fermented with the roseoflavinresistant strain provided 28 per cent of the recommended daily intake (RDI), whereas the product resulting from the fermentation with the wild-type strains provided 11 per cent of the RDI, both were significantly superior to the unfermented soymilk which provided only 4.6 per cent of the RDI.

Guru and Viswanathan (2013) inoculated Lactobacillus acidophilus and L. lactis to milk whey medium for production of riboflavin and the vitamin produced was estimated at periodical intervals using HPLC. It was observed that $L$. acidophilus yielded a higher riboflavin compared to L. lactis. Further, L. acidophilus yielded a maximum riboflavin content of $2930 \mu \mathrm{g} /$ litre on 7th day in whey and declined on 9th day of fermentation. However, it yielded a maximum riboflavin content of $2610 \mu \mathrm{g} /$ litre till 5th day and declined thereafter. Among the isolates of Lactobacillus, LB5 yielded maximum riboflavin $(2930 \mu \mathrm{g} /$ liter $)$ on the 7 th day of fermentation. They showed that whey served as a better fermentation medium compared to skim milk. Similarly, a novel fermented product containing $P$. freudenreichii $\mathrm{B} 2336$, with increased levels of riboflavin was obtained (Le Blanc et al., 2006). Consumption of such products with increased levels of riboflavin on a regular basis may help prevent deficiencies of this essential vitamin.

In the present study, in terms of the acceptability index also, N2 and Ra1 were the promising treatments with 95.37 and 94.44 per cent, respectively (Table 2). Excellent flavor and taste exhibited by the isolates may be due to high lactic acid production by these isolates. Texture and smooth cutting quality of the curd due to inoculation with these isolates may be due to exopolysaccharide production by these isolates. Behare et al. 
Table 1. Preparation of functional curd using riboflavin producing LAB isolates.

\begin{tabular}{|c|c|c|c|c|c|c|c|c|}
\hline $\begin{array}{l}\text { S. } \\
\text { N. }\end{array}$ & Treatment & $\begin{array}{l}\text { Consis- } \\
\text { tency }\end{array}$ & $\begin{array}{l}\text { Color ac- } \\
\text { ceptability }\end{array}$ & Flavor & Taste & Texture & $\begin{array}{l}\text { Cutting } \\
\text { quality }\end{array}$ & $\begin{array}{l}\text { Riboflavin } \\
\text { concentra- } \\
\text { tion }(\mathrm{mg} / \mathrm{L})\end{array}$ \\
\hline 1 & $\begin{array}{l}\text { Milk + Curd } \\
\text { culture }\end{array}$ & Good & Good & $\begin{array}{l}\text { Very- } \\
\text { Good }\end{array}$ & $\begin{array}{l}\text { Very } \\
\text { Good }\end{array}$ & Excellent & Smooth & 5.77 \\
\hline 2 & $\begin{array}{l}\text { Milk + Curd } \\
\text { Culture + N2 }\end{array}$ & Excellent & Good & Excellent & $\begin{array}{l}\text { Very } \\
\text { Good }\end{array}$ & $\begin{array}{l}\text { Very } \\
\text { Good }\end{array}$ & Smooth & 7.43 \\
\hline 3 & $\begin{array}{l}\text { Milk + Curd } \\
\text { Culture + F2 }\end{array}$ & Poor & Poor & Poor & Poor & Poor & Liquid & 10.6 \\
\hline 4 & $\begin{array}{l}\text { Milk + Curd } \\
\text { Culture + Ra } 1\end{array}$ & Very Good & Good & Excellent & $\begin{array}{l}\text { Excel- } \\
\text { lent }\end{array}$ & $\begin{array}{l}\text { Very } \\
\text { Good }\end{array}$ & Smooth & 13.97 \\
\hline
\end{tabular}

Note: Values in the table indicate mean of two replicates.

Table 2. Sensory evaluation of the functional curd.

\begin{tabular}{llllll}
\hline \multirow{2}{*}{ S. N } & \multicolumn{1}{c}{ Particulars } & \multicolumn{3}{c}{ Treatments } \\
\cline { 3 - 6 } & & Milk+Curd & Milk+Curd+ N2 & Milk+Curd + F2 & Milk+Curd+Ra1 \\
\hline 1 & Consistency & 7.5 & 9.0 & 5.0 & 8.0 \\
2 & Color acceptability & 7.0 & 7.5 & 4.5 & 7.5 \\
3 & Flavor & 8.5 & 9.0 & 5.0 & 9.0 \\
4 & Taste & 8.5 & 8.5 & 5.0 & 9.0 \\
5 & Texture & 9.0 & 8.5 & 5.0 & 8.5 \\
6 & Cutting quality & 9.0 & 9.0 & 4.5 & 5.0 \\
7 & Total score & 49.5 & 51.5 & 29.0 & 94.0 \\
8 & Acceptability index (\%) & 91.66 & 95.37 & 53.70 & 94.44 \\
\hline
\end{tabular}

Note: Values in the table indicate score on Hedonic scale have no units.

(2013) showed that low fat dahi could be prepared by using exopolysaccharide producing L. fermentum V10 which exhibited optimum acid production, lesser whey separation, higher viscosity, increased adhesiveness as compared to control dahi. L. fermentum V10 showed large capsules surrounding the cell surface and produced $247.37 \pm 0.76 \mathrm{mg} / \mathrm{L}$ polysaccharides in the fermentation medium. Thus, inoculating riboflavin synthesizing $\mathrm{LAB}$ isolates to curd can be an interesting and economically feasible biotechnology strategy that could be easily adapted by the food industry to develop novel vitamin-bioenriched functional foods with enhanced consumer appeal.

\section{Conclusion}

From the present study, it was shown that by inoculating with riboflavin producing strains, a functional curd with high acceptability index and riboflavin content could be produced. Amongst three strains used, N2 strain showed the best results with the highest acceptability index of 95.37 and riboflavin content of $13.47 \mathrm{ppm}$.

\section{REFERENCES}

AOAC. (1995). Official Methods of Analysis, 16th Edn. Association of Official Analytical Chemists, Washington D.C.

Behare, V.P., Rameshwar Singh., Ravinder Nagpal. and K.H. Rao. (2013). Exopolysaccharide producing Lactobacillus fermentum strain for enhancing rheological and sensory attributes of low-fat dahi. J. Food Sci. Technol., 50:1228-1232.

Boisvert, W.A., Castaneda, C., Mendoza, I., Langeloh, G., Solomons, N.W., Gershoff, S.N. and Russell R.M. (1993). Prevalence of riboflavin deficiency among Guatemalan elderly people and its relationship to milk intake. Am. J Clin. Nutr. 58: 85-90.

Capozzi, V., Menga, V., Digesu, A.M., De Vita, P., van Sinderen, D., Cattivelli, L., Fares, C., and Spano, G. (2011). Biotechnological production of vitamin B2enriched bread and pasta. J. Agric. Food Chem., 59: 8013-8020.

de Man, J. C., Rogosa, M., and Sharpe, M. Z. (1960). A medium for the cultivation of lactobacilli. J. Appl. Microbiol., 23: 130-135.

Del Valle, Jaurez, M., J.E., Laino. G., Savoy., de Giori, J.G. and LeBbanc. (2014). Riboflavin producing lactic acid bacteria as a biotechnological strategy to obtain bioenriched soymilk. Food. Res. Intl. 62: 1015-1019.

Guru, V. and Viswanathan, K. (2013). Riboflavin proction in milk whey using probiotic bacteria- Lactobacillus acidophilus and L. lacis. Ind. J. Fundamental Appl. Life Sci., 3: 169-176.

Kojic, M., Vujcic, M., Banina, A., Cocconcelli, P., Cerning, J. and Topisirovic, L. (1992). Analysis of exopolysaccharide production by Lactobacillus casei CG11, isolated from cheese. Appl. Environ., Microbiol., 58: 12 -22 .

Le Blanc, J.G., Rutten, G., Bruinenberg, P., and Sesma, F. (2006). A novel dairy product fermented with Propionibacterium freudenreichii improves the riboflavin status of deficient rats. Nutrition., 22: 645-651. 
Meilgaard, M., Civile, G.V. \& Carr, B.T., (2007). Sensory Evaluation Techniques, 4th Edition. Florida, USA: CRC Press.1-464.

Sauer, U., Hatzimanikatis, V., Hohmann, H.P., Manneberg, M., van Loon, A.P.G.M. and Bailey, J.E., (1996). Physiology and metabolic fluxes of wild-type and riboflavinproducing Bacillus subtilis. Appl. Environ. Microbiol. 62: 3687-3696.

Stahmann, K.P., Revuelta, J.L., Seulberger, H. (2004). Three biotechnical processes using Ashbya gossypii, Candida famata, or Bacillus subtilis compete with chemical ribofla- vin production. Appl Microbiol Biotechnol., 53: 509-516.

Stiles, M.E. (2004). Bio preservation by lactic acid bacteria. Antonie van Leeuwenhoek, 70: 331-345.

Sybesma, W., Burgess, C., Starrenburg, M., van Sinderen, D. and Hugenholtz, J. (2004). Multivitamin production in Lactococcus lactis using metabolic engineering. Met. Engg., 6:109-115.

Vitreschak A.G., Rodionov D.A., Mironov A.A. and Gelfand M.S. (2002). Regulation of riboflavin biosynthesis and transport genes in bacteria by transcriptional and translational attenuation. Nucleic Acids Res., 30: 3141-3151. 